\title{
Allogeneic Hematopoietic Stem Cell Transplantation for a BCR-FGFR1 Myeloproliferative Neoplasm Presenting as Acute Lymphoblastic Leukemia
}

\author{
Karl Haslam, ${ }^{1}$ Stephen E. Langabeer, ${ }^{1}$ Johanna Kelly, ${ }^{2}$ Natasha Coen, ${ }^{2}$ \\ Niamh M. O'Connell, ${ }^{3}$ and Eibhlin Conneally ${ }^{3}$ \\ ${ }^{1}$ Cancer Molecular Diagnostics, Central Pathology Laboratory, St. James's Hospital, Dublin 8, Ireland \\ ${ }^{2}$ National Centre for Medical Genetics, Our Lady's Children's Hospital, Dublin 12, Ireland \\ ${ }^{3}$ Department of Haematology, St. James's Hospital, Dublin 8, Ireland
}

Correspondence should be addressed to Stephen E. Langabeer, slangabeer@stjames.ie

Received 11 July 2012; Accepted 2 September 2012

Academic Editors: E. Arellano-Rodrigo, N. Hamerschlak, K. Konstantopoulos, and K. Nakase

Copyright ( $) 2012$ Karl Haslam et al. This is an open access article distributed under the Creative Commons Attribution License, which permits unrestricted use, distribution, and reproduction in any medium, provided the original work is properly cited.

\begin{abstract}
Hematopoietic myeloproliferative neoplasms (MPNS) with rearrangements of the receptor tyrosine kinase FGFR1 gene, located on chromosome $8 \mathrm{p} 11$, are uncommon and associated with diverse presentations such as atypical chronic myeloid leukemia, acute myeloid leukemia, or an acute T- or B-lymphoblastic leukemia, reflecting the hematopoietic stem cell origin of the disease. A review of MPN patients with the $\mathrm{t}(8 ; 22)$ translocation that results in a chimeric BCR-FGFR1 fusion gene reveals that this disease either presents or rapidly transforms into an acute leukemia that is generally unresponsive to currently available chemotherapeutic regimens including tyrosine kinase inhibitors (TKIS). The first case of a rare BCR-FGFR1 MPN presenting in a Bacute lymphoblastic phase who underwent allogeneic hematopoietic stem cell transplantation (HSCT) with a subsequent sustained complete molecular remission is described. Allogeneic HSCT is currently the only available therapy capable of achieving long-term remission in BCR-FGFR1 MPN patients.
\end{abstract}

\section{Introduction}

The fibroblast growth factor receptor 1 (FGFR1) gene, located on chromosome $8 \mathrm{p} 11$, encodes a receptor tyrosine kinase. Upon ligand binding, receptor dimerization occurs with subsequent autophosphorylation and recruitment of target proteins PLC- $\gamma$ and effectors of the RAS/MAPK signalling pathway essential for normal cellular proliferation and differentiation [1]. Rearrangements of FGFR1 are associated with a heterogeneous set of hematological malignancies thought to be derived from a pluripotent haematopoietic stem cell that may present as an atypical myeloproliferative neoplasm, a lymphoblastic lymphoma, or in transformation to either a myeloid or lymphoid acute leukemia in which eosinophilia is characteristic but not invariable [2]. The defining molecular feature of this group of neoplasms is evidence of balanced translocations of FGFR1 to one of several genes, most frequently ZMYM2 at 13q11, and also to FOP (6q27), CEP110 (9q33), BCR (22q11), and several other partner genes [2]. The resulting fusion genes retain the C-terminal portion of FGFR1 and lead to constitutive ligand-independent aberrant tyrosine kinase activation with some evidence that the partner gene of FGFR1 influences the phenotype of the disease [3]. The disease is associated with a high risk of progression to acute leukemia and in the absence of an available specific TKI therapy, the only potentially curative option is allogeneic HSCT which should be considered even in those eligible patients in the chronic phase of the disease $[4,5]$.

The recurrent $\mathrm{t}(8 ; 22)(\mathrm{p} 11 ; \mathrm{q} 11)$ translocation, that results in a BCR-FGFR1 fusion, has to date been reported in only twelve adult patients [6-16] and one pediatric patient [17] (Table 1). Therapy has varied depending on the phenotype of the disorder with patients presenting in an acute leukemic phase rarely achieving long-term remission. We present a case of BCR-FGFR1 MPN which presented in 
TABLE 1: Summary of presenting and clinical features of previously reported BCR-FGFR1 patients.

\begin{tabular}{|c|c|c|c|c|c|c|c|}
\hline Case & Reference & Age & Gender & Diagnosis & Treatment & Response & Outcome \\
\hline (1) & {$[6]$} & 65 & $\mathrm{~F}$ & Atypical CML & $\mathrm{HU} / \mathrm{IFN}$ & Unknown & Unknown \\
\hline (2) & {$[6]$} & 51 & $\mathrm{~F}$ & Atypical CML & HU/IFN & Unknown & Unknown \\
\hline \multirow{2}{*}{ (3) } & \multirow{2}{*}[7]{} & \multirow{2}{*}{75} & \multirow{2}{*}{ M } & Atypical CML & & & \\
\hline & & & & AML transformation & HU/cytarabine & Partial hematological response & Unknown \\
\hline (4) & {$[8]$} & 74 & $\mathrm{~F}$ & Atypical CML & $\mathrm{HU}$ & Partial hematological response & Unknown \\
\hline \multirow{2}{*}{ (5) } & \multirow[t]{2}{*}[9]{} & \multirow{2}{*}{68} & \multirow{2}{*}{ M } & Atypical MPN & & & \\
\hline & & & & LBC & $\mathrm{HU}$ & No hematological response & Unknown \\
\hline \multirow[t]{3}{*}{ (6) } & \multirow{3}{*}[10]{} & \multirow[t]{3}{*}{58} & \multirow[t]{3}{*}{$\mathrm{F}$} & Atypical CML & & & \\
\hline & & & & AML transformation & & Unknown & Unknown \\
\hline & & & & Atypical CML & $\mathrm{HU} / \mathrm{IFN}$ & $\begin{array}{l}\text { Minimal hematological and } \\
\text { cytogenetic response }\end{array}$ & \\
\hline \multirow[t]{2}{*}{ (7) } & \multirow[t]{2}{*}[11]{} & \multirow[t]{2}{*}{56} & \multirow[t]{2}{*}{$\mathrm{F}$} & & Cytarabine/IFN/ATO & No hematological response & \\
\hline & & & & AML transformation & Daunorubicin/cytarabine & Bone marrow aplasia & Deceased \\
\hline (8) & {$[12]$} & 50 & $\mathrm{~F}$ & $\mathrm{CML} \mathrm{AP} \rightarrow \mathrm{BC}$ & Unknown & Unknown & Deceased \\
\hline \multirow[t]{2}{*}{ (9) } & \multirow[t]{2}{*}[13]{} & \multirow[t]{2}{*}{70} & \multirow[t]{2}{*}{$\mathrm{F}$} & B-ALL & $\begin{array}{l}\text { Induction/consolidation/ } \\
\text { maintenance chemotherapy }\end{array}$ & $\begin{array}{l}\text { Morphological remission yet } \\
\text { persistent } \mathrm{t}(8 ; 22)\end{array}$ & \\
\hline & & & & Atypical MPN & $\mathrm{HU} /$ maintenance & Disease progression & Deceased \\
\hline$(10)$ & {$[14]$} & 57 & $\mathrm{~F}$ & Atypical MPN & AHSCT & $\begin{array}{l}\text { Remission for } 42 \text { months post } \\
\text { AHSCT }\end{array}$ & Alive \\
\hline \multirow[t]{2}{*}{ (11) } & \multirow[t]{2}{*}[15]{} & \multirow[t]{2}{*}{59} & \multirow[t]{2}{*}{ M } & \multirow[t]{2}{*}{ T-LBL/MPN } & $\begin{array}{l}\text { Cytarabine/daunorubicin/ } \\
\text { vincristine/prednisone }\end{array}$ & Persistent t $(8 ; 22)$ & \\
\hline & & & & & AHSCT & Cytogenetic remission & Alive \\
\hline \multirow{3}{*}{$(12)$} & \multirow{3}{*}[16]{} & \multirow{3}{*}{43} & \multirow{3}{*}{ M } & B-ALL & HyperCVAD & $\begin{array}{l}\text { Remission yet leukocytosis and } \\
\text { splenomegaly }\end{array}$ & \\
\hline & & & & Atypical CML & HU/Sorafenib & $\begin{array}{l}\text { Partial haematological } \\
\text { response/relapse }\end{array}$ & \\
\hline & & & & B-ALL & Sorafenib/FLA-Ida (no G-CSF) & $\begin{array}{l}\text { Persistent B-ALL/AML } \\
\text { transformation }\end{array}$ & Deceased \\
\hline (13) & {$[17]$} & 8 & M & MDS/MPN & HU/AHSCT & $\begin{array}{l}\text { Remission for } 54 \text { months post } \\
\text { AHSCT }\end{array}$ & Alive \\
\hline
\end{tabular}

CML: chronic myeloid leukemia; HU: hydroxyurea; IFN: interferon-alpha; AML: acute myeloid leukemia; MPN: myeloproliferative neoplasm; LBC: lymphoid blast crisis; ATO: arsenic trioxide; AP: accelerated phase; BC: blast crisis; ALL: acute lymphoblastic leukemia; T-LBL, T-lymphoblastic lymphoma; MDS: myelodysplastic syndrome; AHSCT: allogeneic hematopoietic stem cell transplantation; hyperCVAD: hyper-fractionated cyclophosphamide, vincristine, doxorubicin, dexamethasone; FLA-Ida: fludarabine, cytarabine, idarubicin.

an acute lymphoblastic phase demonstrating a favorable outcome following allogeneic HSCT.

\section{Case Report}

A 21-year-old male presented with a facial palsy and peripheral leukocytosis. Physical examination revealed features of meningism but no other abnormalities. His presenting FBC revealed hemoglobin $13.1 \mathrm{~g} / \mathrm{L}$, white cell count $78.2 \times$ $10^{9} / \mathrm{L}$, and platelets of $167 \times 10^{9} / \mathrm{L}$. A review of the peripheral blood film showed predominantly neutrophils, with an increase in basophils, metamyelocytes, and myelocytes and occasional circulating blast cells. His LDH at presentation was elevated at $971 \mathrm{IU} / \mathrm{L}$ (normal range 230-450 IU/L). Bone marrow aspirate examination showed a hypercellular marrow with an infiltrate of lymphoid appearing blast cells $(62 \%)$ (Figure 1(a)). Multicolor flow cytometry of these blast cells demonstrated expression of CD34, HLA-DR, CD10, CD19, CD71, nuclear TdT and cytoplasmic CD79a and CD22, consistent with precursor B-cell acute lymphoblastic leukemia (B-ALL). Flow cytometry also demonstrated a population of dual CD19/CD34 positive cells in cerebrospinal fluid, corroborating central nervous system involvement. The bone marrow karyotype showed a balanced 


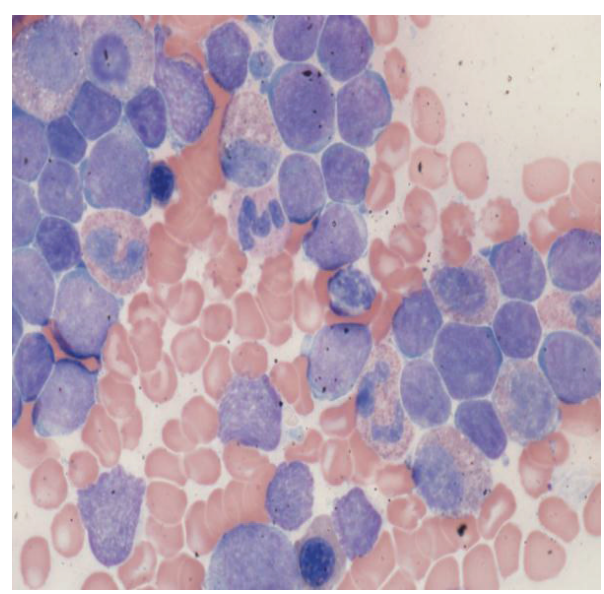

(a)

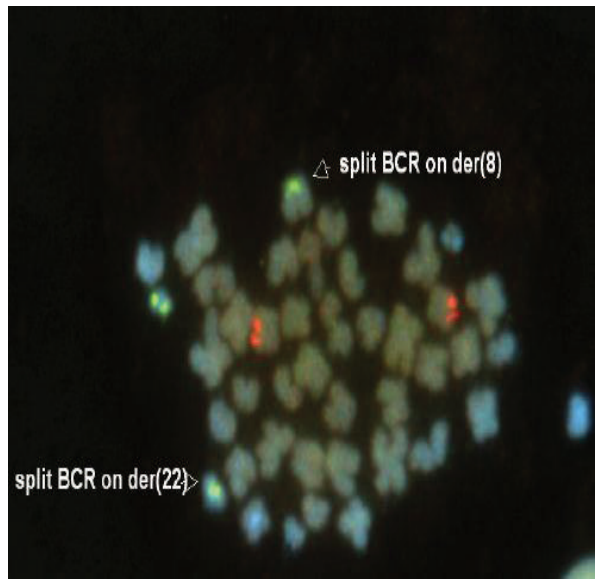

(c)

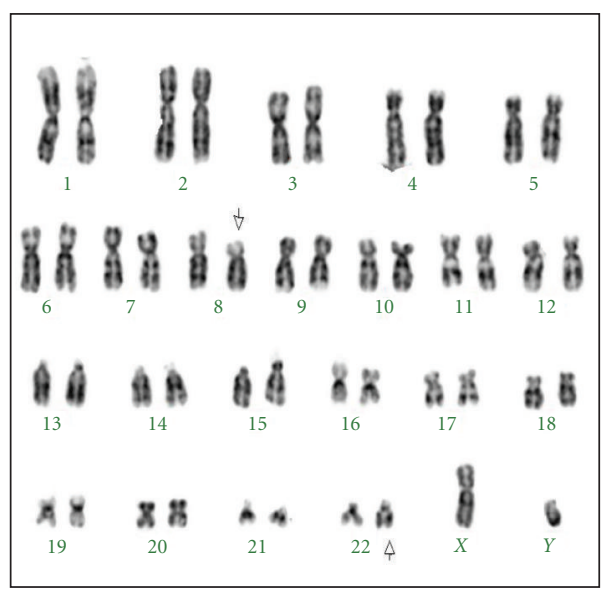

(b)

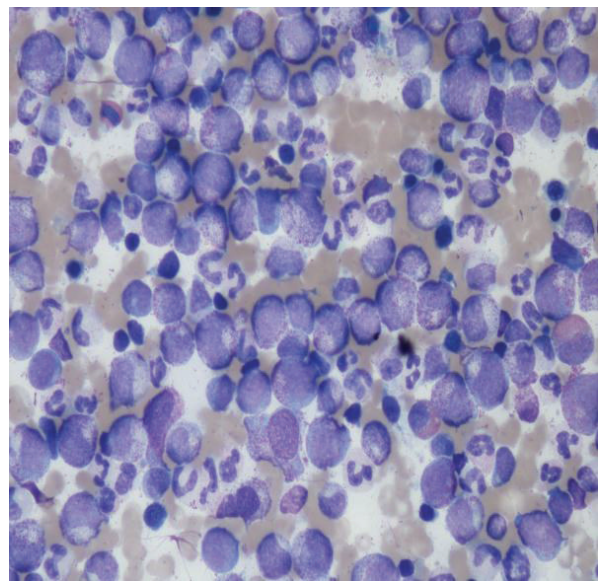

(d)

Figure 1: (a) Presenting bone marrow aspirate showing large lymphoblasts; (b) karyotype depicting $\mathrm{t}(8$; 22) translocation highlighted by arrows; (c) FISH demonstrating a split BCR signal on chromosomes 8 and 22; (d) bone marrow aspirate with myeloid hyperplasia consistent with an atypical MPN.

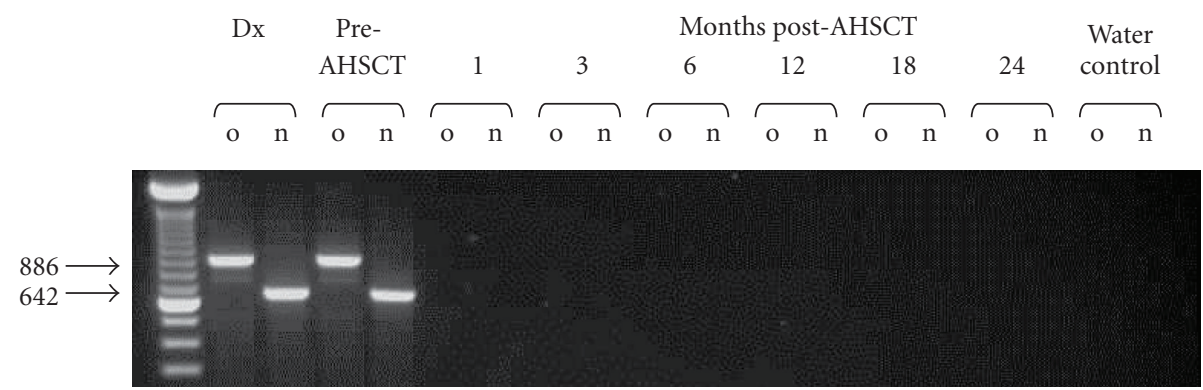

FIGURE 2: RT-PCR of BCR-FGFR1 transcripts at diagnosis and throughout treatment course. Dx: diagnosis; o: outer; n: nested.

translocation between chromosomes 8 and 22 as the primary karyotypic event with evidence of clonal evolution in the form of a further whole arm translocation, a dicentric and a ring chromosome in eleven metaphases analysed: 46,XY,t $(8 ; 22)(\mathrm{p} 12 ; \mathrm{q} 11)$ [8]/45,idem,der(3; 9)(q10; $\mathrm{q} 10), \operatorname{dic}(7 ; 11)(\mathrm{p} 11 ; \mathrm{q} 13),+\mathrm{r}[\mathrm{cp} 3]$ (Figure 1(b)). Fluorescent in situ hybridization (FISH) analysis demonstrated the presence of a split BCR (22q11) signal, with signals located on both the $\operatorname{der}(8)$ and $\operatorname{der}(22)$ in 170/200 cells (Figure 1(c)). Additional FISH with an 11q23 probe set showed loss of an $M L L$ signal in a smaller subset of cells (59/200). Seminested reverse transcriptase-PCR using forward primers BCR-e1-A and BCR-E1+ and reverse primer FGFR9- $[6,18]$ confirmed the presence of $B C R-F G F R 1$ transcripts at the molecular level without expression of the reciprocal FGFR1-BCR fusion (Figure 2). 
The patient was initially treated according to an adolescent ALL protocol (UKALL 2003) [19]. After one cycle of chemotherapy, the bone marrow was hypercellular marrow consistent with a myeloproliferative disorder with resolution of the ALL. Interphase FISH demonstrated persistence of the $t(8 ; 22)$ clone in $262 / 300$ cells. In the absence of a human leukocyte antigen compatible sibling, a search for an unrelated donor was initiated. The patient continued on the UKALL 2003 protocol and received phase II induction and high-dose methotrexate. Four months after diagnosis, prior to the planned allogeneic HSCT, the patient developed a rapidly increasing peripheral white cell count with a review of the blood film consistent with an accelerated phase of the myeloproliferative component of his disease. The bone marrow aspirate showed evidence of the primary MPN with marked myeloid hyperplasia, increased numbers of megakaryocytes, and an absence of blasts (Figure 1(d)). Cytogenetics confirmed the presence of $\mathrm{t}(8 ; 22)$ as the sole aberration in all 30 cells analysed. The patient received FLAG-Ida chemotherapy which reduced the cellularity and rapidly progressed to a myeloablative, mismatched, unrelated donor HSCT. His conditioning regimen consisted of cyclophosphamide/total body irradiation with antithymocyte globulin added due to the B-antigen mismatch. The initial transplant course was unremarkable; however, on engraftment, he developed grade II skin graft-versus-host disease (GVHD) and required therapy with corticosteroids. BCR-FGFR1 RT-PCR was performed at regular intervals and demonstrated molecular remission at one month after allogeneic HSCT with concurrent peripheral blood full-donor chimerism [20]. The patient remains clinically well two years after allogeneic HSCT with extensive chronic GVHD requiring ongoing therapy with Tacrolimus, low-dose corticosteroids, and mycophenolate mofetil with sustained undetectable BCR-FGFR1 transcripts (Figure 2). Despite this, the patient has returned to full-time education and his current Karnofsky score is $80 \%$.

\section{Discussion}

BCR-FGFR1 MPN is a rare disease that manifests as diverse phenotypes attesting to the proposal that the transforming genetic defect occurs in a pluripotent hematopoietic stem cell capable of multilineage differentiation and further corroborated in the patient described herein whereby initial successful treatment of the presenting acute leukemia revealed the underlying MPN. A recently described murine model recapitulates the human disease with bilineage myeloid and B-cell involvement [21]. Though usually presenting as an atypical chronic myeloid leukemia, the present case is the fourth BCR-FGFR1-positive patient diagnosed with lymphoblastic leukemia (Table 1) suggesting that specific domains or amino acid residues of the translocation partner protein of FGFR1 may not be the dominant factor that influences the presenting phenotype [22]. Cellular mechanisms responsible for this phenotypic diversity may include the absolute stage of stem cell differentiation in which the genetic lesion arises, the intensity of resulting kinase activation or perturbations in pathways analogous to those known to be involved in
BCR-ABL1-dependent blast crisis transformation of CML such as a block of myeloid differentiation, enhanced selfrenewal, or proliferation and survival characteristics of leukemic stem cells $[3,23]$.

In the postallogeneic HSCT period, molecular monitoring utilizing both BCR-FGFR1 RT-PCR and microsatellite donor chimerism analysis was performed to detect any evidence of minimal residual disease (MRD). Donor lymphocyte infusions have been shown to offer potential in eliminating MRD by mediating graft-versus-leukemia activity in a previous case of ZMYM2-FGFR1 MPN [5] and which may have been achieved in this case by the ongoing chronic GVHD.

Several tyrosine kinase inhibitors have been shown to be active in vitro against transformed cell lines and primary cells bearing FGFR1 kinase fusions [24, 25] but have limited long-term efficacy in vivo [26, 27]. Development of more potent TKIs, such as the broad-spectrum ponatinib, active against resistant mutations of FLT3 and BCR-ABL1 in acute and chronic myeloid leukemia, respectively, may be of future clinical benefit in FGFR1 MPN [28-30].

This is the first description of a patient with a BCRFGFR1 MPN presenting with B-ALL who has undergone allogeneic HSCT: three previously described patients presenting with either an atypical MPN or a T-lymphoblastic lymphoma all achieved a complete remission and were alive at last reported followup after allogeneic HSCT. This case confirms the stem cell nature of $t(8 ; 22) \mathrm{MPN}$ and provides further evidence that, in the absence of currently available efficacious TKI therapy, allogeneic HSCT is the only potentially curative option for this clinically aggressive disease.

\section{References}

[1] C. C. Jackson, L. J. Medeiros, and R. N. Miranda, "8p11 myeloproliferative syndrome: a review," Human Pathology, vol. 41, no. 4, pp. 461-476, 2010.

[2] B. J. Bain, D. G. Gilliland, H. -P. Horny, and J. W. Vardiman, "Myeloid and lymphoid neoplasms with eosinophilia and abnormalities of PDGFRA, PDGFRB and FGFR1," in WHO Classification of Tumours of Haematopoietic and Lymphoid Tissues, S. H. Swerdlow, E. Campo, and N. L. Harris, Eds., pp. 68-73, IARC, Lyon, France, 2008.

[3] A. Holroyd, N. C. P. Cross, and D. H. Macdonald, "The two faces of myeloproliferative neoplasms: molecular events underlying lymphoid transformation," Leukemia Research, vol. 35, no. 10, pp. 1279-1285, 2011.

[4] F. Suzan, G. Guasch, C. Terre et al., "Long-term complete haematological and molecular remission after allogeneic bone marrow transplantation in a patient with a stem cell myeloproliferative disorder associated with $\mathrm{t}(8 ; 13)(\mathrm{p} 12 ; \mathrm{q} 12)$," British Journal of Haematology, vol. 121, no. 2, pp. 312-314, 2003.

[5] W. Townsend, N. C. P. Cross, K. Waghorn et al., "Clinical evidence for a graft-versus-tumour effect following allogeneic HSCT for $\mathrm{t}(8 ; 13)$ atypical myeloproliferative disorder," Bone Marrow Transplantation, vol. 44, no. 3, pp. 197-199, 2009.

[6] A. Demiroglu, E. Joanna Steer, C. Heath et al., "The $t(8 ; 22)$ in chronic myeloid leukemia fuses BCR to FGFR1: transforming activity and specific inhibition of FGFR1 fusion proteins," Blood, vol. 98, no. 13, pp. 3778-3783, 2001. 
[7] T. Fioretos, I. Panagopoulos, C. Lassen et al., "Fusion of the BCR and the fibroblast growth factor receptor-1 (FGFR1) genes as a result of $t(8 ; 22)(\mathrm{p} 11 ; \mathrm{q} 11)$ in a myeloproliferative disorder: the first fusion gene involving BCR but not ABL," Genes Chromosomes and Cancer, vol. 32, no. 4, pp. 302-310, 2001.

[8] M. Pini, E. Gottardi, P. Scaravaglio et al., "A fourth case of BCR-FGFR1 positive CML-like disease with $\mathrm{t}(8 ; 22)$ translocation showing an extensive deletion on the derivative chromosome 8p," Hematology Journal, vol. 3, no. 6, pp. 315-316, 2002.

[9] A. Murati, C. Arnoulet, M. Lafage-Pochitaloff et al., "Dual lympho-myeloproliferative disorder in a patient with $\mathrm{t}(8 ; 22)$ with BCR-FGFR1 gene fusion," International Journal of Oncology, vol. 26, no. 6, pp. 1485-1492, 2005.

[10] H. Ågerstam, H. Lilljebjörn, C. Lassen et al., "Fusion genemediated truncation of RUNX1 as a potential mechanism underlying disease progression in the $8 \mathrm{p} 11$ myeloproliferative syndrome," Genes Chromosomes and Cancer, vol. 46, no. 7, pp. 635-643, 2007.

[11] S. Richebourg, O. Theisen, I. Plantier et al., "Chronic myeloproliferative disorder with $\mathrm{t}(8 ; 22)(\mathrm{p} 11 ; \mathrm{q} 11)$ can mime clonal cytogenetic evolution of authentic chronic myelogeneous leukemia," Genes Chromosomes and Cancer, vol. 47, no. 10, pp. 915-918, 2008.

[12] S. G. Lee, T. S. Park, S. T. Lee et al., "Rare translocations involving chromosome band 8p11 in myeloid neoplasms," Cancer Genetics and Cytogenetics, vol. 186, no. 2, pp. 127-129, 2008.

[13] C. Baldazzi, I. Iacobucci, S. Luatti et al., "B-cell acute lymphoblastic leukemia as evolution of a 8 p11 myeloproliferative syndrome with $\mathrm{t}(8 ; 22)(\mathrm{p} 11 ; \mathrm{q} 11)$ and BCR-FGFR1 fusion gene," Leukemia Research, vol. 34, no. 10, pp. e282-e285, 2010.

[14] M. M. Patnaik, N. Gangat, R. A. Knudson et al., "Chromosome 8p11.2 translocations: prevalence, FISH analysis for FGFR1 and MYST3, and clinicopathologic correlates in a consecutive cohort of 13 cases from a single institution," American Journal of Hematology, vol. 85, no. 4, pp. 238-242, 2010.

[15] S. Y. Kim, B. Oh, C. J. She et al., " 8 p11 myeloproliferative syndrome with BCR-FGFR1 rearrangement presenting with T-lymphoblastic lymphoma and bone marrow stromal cell proliferation: a case report and review of the literature," Leukemia Research, vol. 35, no. 5, pp. e30-e34, 2011.

[16] J. J. Wakim, C. A. Tirado, W. Chen, and R. Collins, "T( $8 ; 22) / B C R-F G F R 1$ myeloproliferative disorder presenting as B-acute lymphoblastic leukemia: report of a case treated with sorafenib and review of the literature," Leukemia Research, vol. 35, no. 9, pp. e151-e153, 2011.

[17] M. Dolan, A. Cioc, N. C. P. Cross, J. P. Neglia, and J. Tolar, "Favorable outcome of allogeneic hematopoietic cell transplantation for $8 \mathrm{p} 11$ myeloproliferative syndrome associated with BCR-FGFR1 gene fusion," Pediatric Blood \& Cancer, vol. 59, no. 1, pp. 194-196, 2011.

[18] J. J. M. Van Dongen, E. A. Macintyre, J. A. Gabert et al., "Standardized RT-PCR analysis of fusion gene transcripts from chromosome aberrations in acute leukemia for detection of minimal residual disease. Report of the BIOMED-1 Concerted Action: investigation of minimal residual disease in acute leukemia," Leukemia, vol. 13, no. 12, pp. 1901-1928, 1999.

[19] A. Qureshi, C. Mitchell, S. Richards, A. Vora, and N. Goulden, "Asparaginase-related venous thrombosis in UKALL 2003- reexposure to asparaginase is feasible and safe," British Journal of Haematology, vol. 149, no. 3, pp. 410-413, 2010.

[20] S. R. McCann, M. Crampe, K. Molloy, and M. Lawler, "Hemopoietic chimerism following stem cell transplantation," Transfusion and Apheresis Science, vol. 32, no. 1, pp. 55-61, 2005.
[21] M. Ren, J. A. Tidwell, S. Sharma, and J. K. Cowell, "Acute progression of BCR-FGFR1 induced murine B-lympho/myeloproliferative disorder suggests involvement of lineages at the pro-B cell stage," PLoS ONE, vol. 7, no. 6, Article ID e38265, 2012.

[22] S. Roumiantsev, D. S. Krause, C. A. Neumann et al., "Distinct stem cell myeloproliferative/T lymphoma syndromes induced by ZNF198-FGFR1 and BCR-FGFR1 fusion genes from 8p11 translocations," Cancer Cell, vol. 5, no. 3, pp. 287-298, 2004.

[23] D. Perrotti, C. Jamieson, J. Goldman, and T. Skorski, "Chronic myeloid leukemia: mechanisms of blastic transformation," Journal of Clinical Investigation, vol. 120, no. 7, pp. 2254-2264, 2010.

[24] A. Chase, F. H. Grand, and N. C. P. Cross, "Activity of TKI258 against primary cells and cell lines with FGFR1 fusion genes associated with the 8p11 myeloproliferative syndrome," Blood, vol. 110, no. 10, pp. 3729-3734, 2007.

[25] B. Wasag, E. Lierman, P. Meeus, J. Cools, and P. Vandenberghe, "The kinase inhibitor TKI258 is active against the novel CUX1-FGFR1 fusion detected in a patient with T-lymphoblastic leukemia/lymphoma and t(7;8)(q22;p11)," Haematologica, vol. 96, no. 6, pp. 922-926, 2011.

[26] J. Chen, D. J. DeAngelo, J. L. Kutok et al., "PKC412 inhibits the zinc finger 198-fibroblast growth factor receptor 1 fusion tyrosine kinase and is active in treatment of stem cell myeloproliferative disorder," Proceedings of the National Academy of Sciences of the United States of America, vol. 101, no. 40, pp. 14479-14484, 2004.

[27] J. J. Wakim, C. A. Tirado, W. Chen, and R. Collins, "T $(8 ; 22)$ /BCR-FGFR1 myeloproliferative disorder presenting as B-acute lymphoblastic leukemia: report of a case treated with sorafenib and review of the literature," Leukemia Research, vol. 35, no. 9, pp. e151-e153, 2011.

[28] E. Lierman, S. Smits, J. Cools, B. Dewaele M, Debiec-Rychter, and P. Vandenberghe, "Ponatinib is active against imatinibresistant mutants of FIP1L1-PDGFRA and KIT, and against FGFR1-derived fusion kinases," Leukemia, vol. 26, no. 7, pp. 1693-1695, 2012.

[29] M. Ren, H. Qin, R. Ren, and J. K. Cowell, "Ponatinib suppresses the development of myeloid and lymphoid malignancies associated with FGFR1 abnormalities," Leukemia. In press.

[30] A. Chase, C. Bryant, J. Score, and N. C. Cross, "Ponatinib as targeted therapy for FGFR1 fusions associated with the 8p11 myeloproliferative syndrome," Haematologica. In press. 


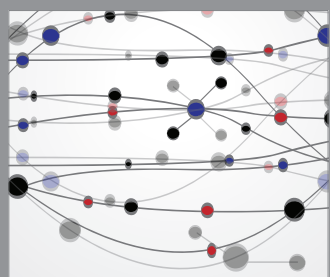

The Scientific World Journal
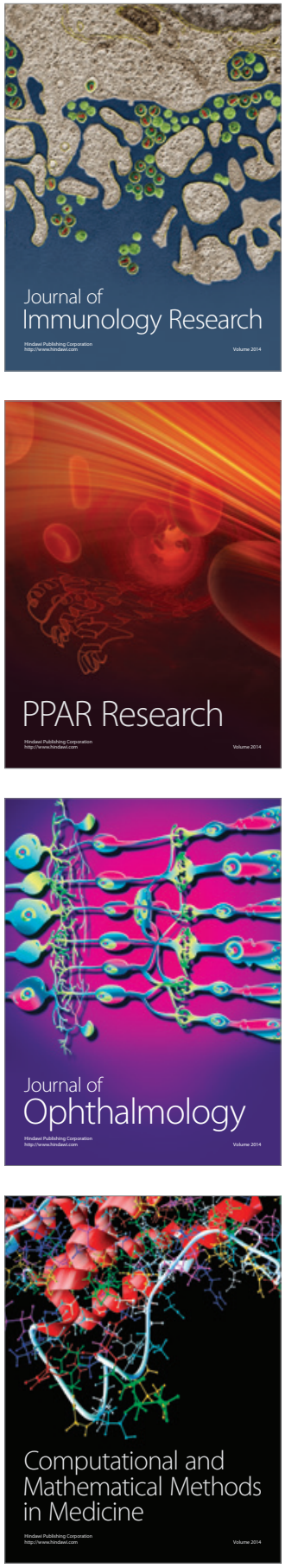

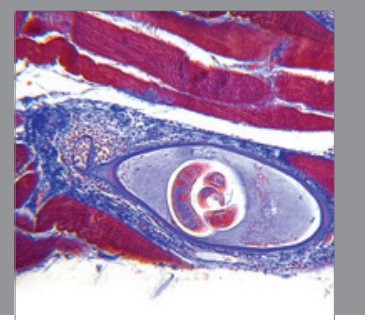

Gastroenterology

Research and Practice
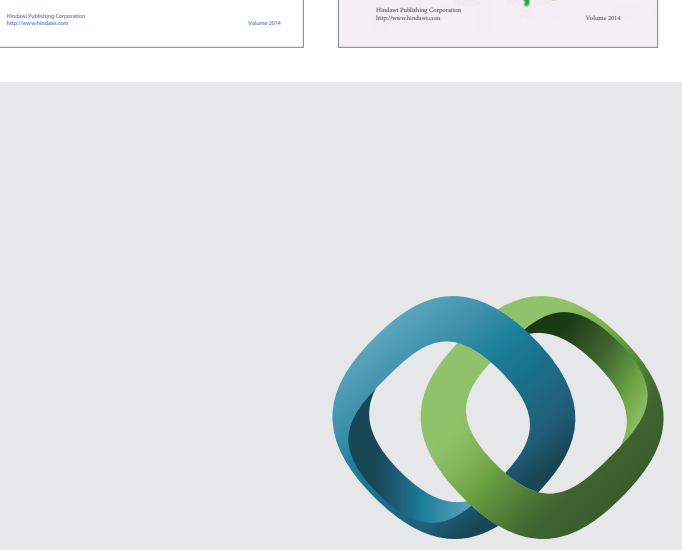

\section{Hindawi}

Submit your manuscripts at

http://www.hindawi.com
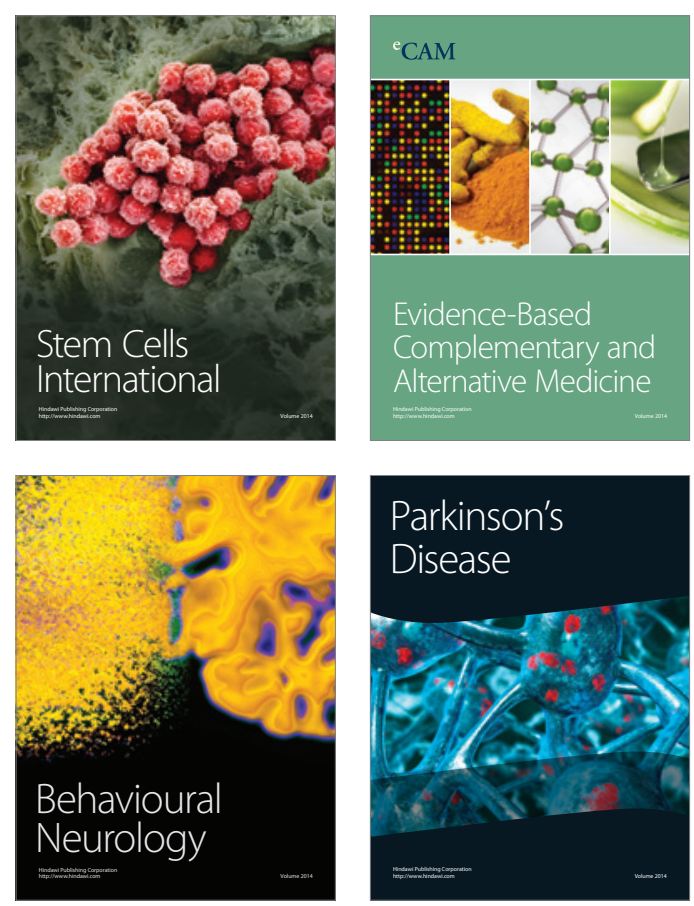

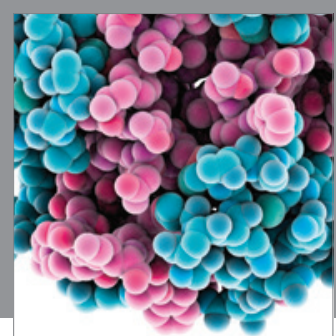

Journal of
Diabetes Research

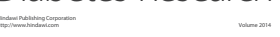

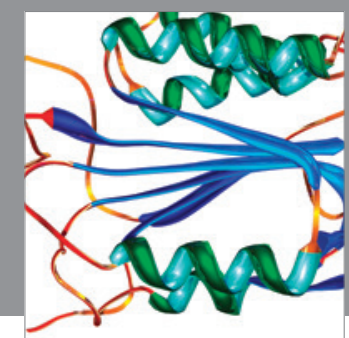

Disease Markers
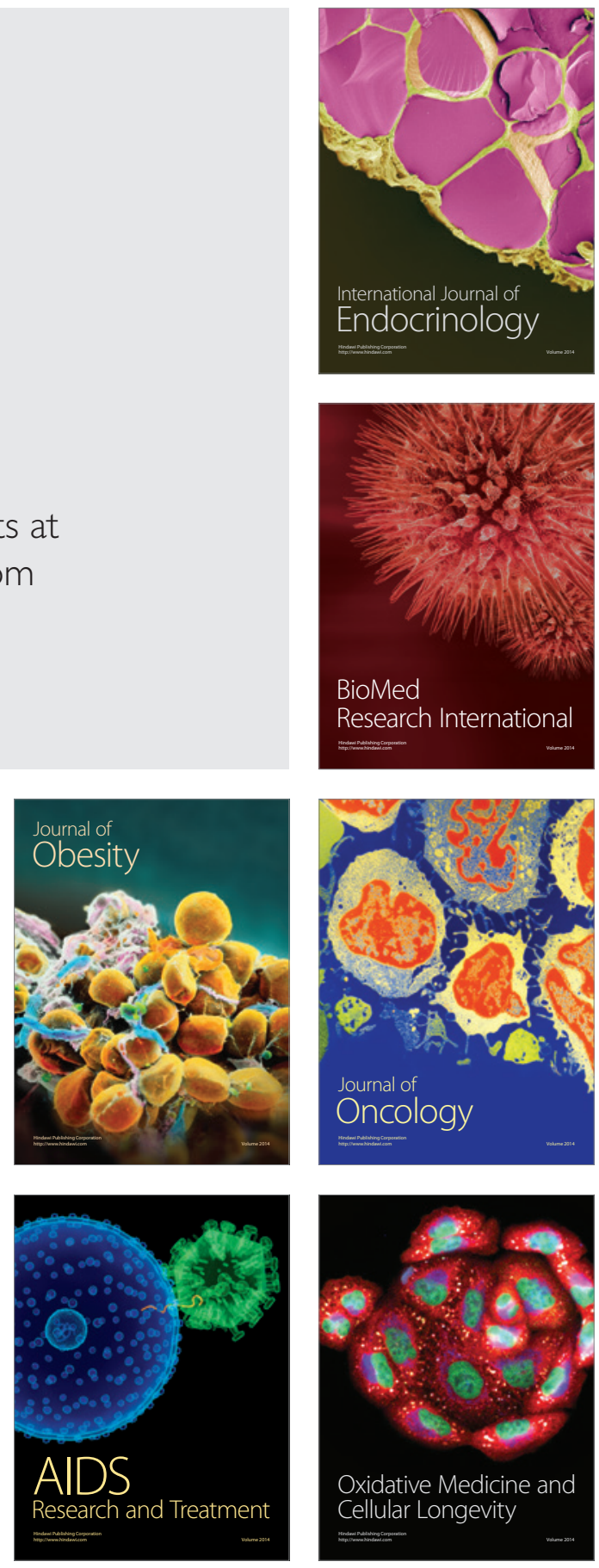